\title{
WHAT QUESTIONS OF MINING LAW HAVE BEEN DECIDED IN THE LITIGATION OVER THE DRUM LUMMON LODE OR VEIN
}

\author{
By John B. Clayberg, of the Montana Bar.
}

The Drum Lummon lode or vein, which is situated in Lewis and Clark County, Montana, is a natural deposit of mineral from which vast amounts of money have been extracted. The peculiar situation of the vein or lode with reference to adjacent mining locations, through which it passes, has been the cause of very extensive litigation which has settled numerous interesting questions, most of which were new in the mining law at the time they arose and were decided. A review of the litigation will disclose these various questions and the decisions of the courts upon them. which will be of interest to that part of the profession who are conversant with mining law and, because of their singularity, may interest the profession generally.

This lode or vein was discovered by an old miner by the name of Thomas Cruse, who located the Drum Lummon quartz lode mining claim on such discovery. Development disclosed its immense value and Mr. Cruse sold it to some Englishmen, who organized the Montana Company, Limited, an English corpora tion, which took over the property and worked it for many years. From time to time, after purchasing the Drum Lummon lode, the Montana Company, Limited, acquired other claims, into or through which this great lode entered or passed, either upon its dip or strike. Other adjoining locations, affected by the lode, were acquired by others, and serious litigation ensued over conflicting rights in this vein or lode. The following map (inserted for the purpose of explaining the location of the vein with reference to the various claims), discloses the surface of the various mining locations along the course or strike of the vein for over two thousand feet. The apex or top of the vein on its strike or course is marked by dotted lines, which indicate the foot and hanging walls of the vein. The hanging wall of a vein is the line of separation belween the vein and the adjoining country rock along 
the upper side of the vein on its dip, and the foot wall is the line of separation between the vein and the adjoining country rock along the lower side of the vein on its dip.

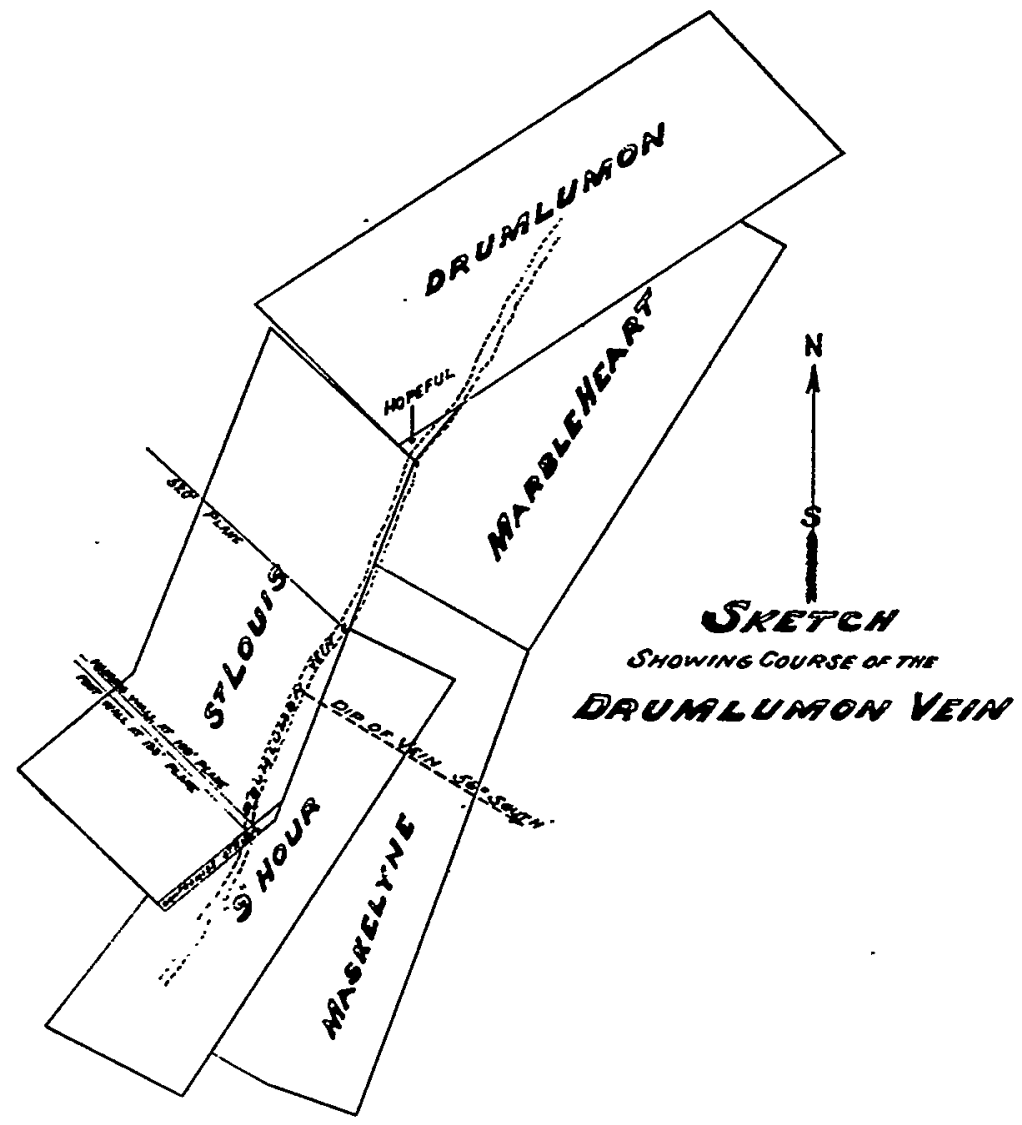

A.

The first litigation in which any questions of interest arose was instituted against the owners of the Hopeful quartz claim, which was a fractional location in the form of a triangle, lying adjacent to the Drum Lummon location, and along the southwesterly portion thereof, as disclosed on the above map by the small triangle marked Hopeful. This suit was brought by the Montana Company, Limited, against Clark and others, owners of the Hopeful clain, for the purpose of enjoining them from sinking a shaft on the vein-following its dip-to such an extent that it 
would break into the Cruse level, so-called, which was a drift or level excavated by the Montana Company, Limited, along the course of the Drum Lummon vein at about 140 feet beneath the surface of the Marble Heart claim, owned by that company. The apex of the Drum Lummon lode at the point where the shaft was started was within the surface boundaries of the Hopeful claim, but the descent of the vein into the earth was at such an angle, that it departed from the vertical boundaries of the Hopeful claim and passed underneath the surface boundaries of the Marble Heart claim above mentioned.

The action was defended by Clark and others, on the theory that having the apex of the lode within the surface boundaries of the Hopeful claim, they had the right to follow the vein on its dip or descent into the earth to its uttermost depth, even though it departed from the vertical boundaries of the Hopeful claim. This right was claimed under what is known as the "extralateral" right grant by Section 2322 R. S. U. S. The right is given by this section to the owners of any quartz mining location to follow all veins having their apices or tops within the vertical boundaries of the claim or location, on their downward course or descent into the earth, although they so far depart from the perpendicular as to pass outside of such vertical boundaries and enter beneath the surface of the adjoining claims. This right extends to the uttermost depth of the vein, but is limited on the strike or course of the vein by vertical planes dropped through the end lines of the location and extended in their own direction until they intersect the vein on the dip. This right is known in mining parlance as the "extralateral right." .

The Montana Company, Limited, contended that the form or shape of the surface of the Hopeful location was such that the claim had no extralateral rights, relying upon the decision of the Supreme Court of the United States in the Horse Shoe Case (so-called), ${ }^{1}$ which held that the end lines of a mining claim must be parallel to each other in order to give such claim extralateral rights. Judge Knowles sustained the company's contention, and held that a mining claim in the form of a triangle and, therefore, having no parallel boundaries, had no extralateral rights. As a matter of fact, the Hopeful claim had been located in the form of a parallelogram, with the Drum Lummon lode or vein on its course or strike, passing through two parallel end lines.

1 II8 U. S., 208. 
Portions of the surface of the claim so located, conflicted with prior locations, and upon the patenting of the Hopeful claim, such conflicting portions were excluded, and title was given only to the remainder of the surface of that claim. Judge Knowles held that under the doctrine of Belk $v$. Meagher, ${ }^{2}$ no ground could be included within the limits of a mining location which was then included within the limits of another existing valid location. The Supreme Court of the United States afterwards held that while the right of possession of only unappropriated public domain could be obtained by location, yet, a locator, for the purpose of securing unappropriated extralateral rights, might set the stakes marking his boundaries, upon other valid locations, and include the land thus bounded in his location, but subject to the rights of prior locations. ${ }^{3}$

This decision of Judge Knowles is an anomaly, holding that the owners of the Hopeful claim had no right to follow the vein on its dip after it passed through any of the vertical boundaries of their location, because the claim had no extralateral rights, owing to its shape or form; that the Montana Company, Limited, did not own the vein beyond that point because it did not own the apex thereof, or the ground in which it was situated; that the government owned, but could not transfer the title to the vein after it passed through the vertical boundaries of the Hopeful claim, without further legislation, because it had sold the land in which the apex of the vein was included, and the statute did not provide for a separate sale or transfer of any portion of a vein, but only the surface ground which included the apex of a vein therein. No appeal was taken in this case because it was ascertained that the particular part or portion of the Drum Lummon vein or lode in controversy therein, was not of sufficient value to warrant further litigation. ${ }^{4}$

B.

The next important litigation regarding the Drum Lummon lode or vein, originated in an application of the owners of the St. Louis claim, for an order of inspection and survey of the workings of the Montana Company, Limited, on the dip of the vein

2104 U. S., 279.

3 Del Monte Mining Co. v. Last Chance Mining Co., $17 \mathrm{I}$ U. S., 55.

1 This case is reported under the the title of Montana Co., Limited, $v$. Clark, 42 Fed., 626. 
underneath the surface of the Marble Heart, the Maskelyne and the Nine-Hour Mining claims for the purpose of ascertaining the amount and value of ore alleged to have been extracted by the Montana Company, Limited, on the dip of the vein and beneath the surface boundaries of their locations, and claimed by the St. Louis Company because extracted from a vein which apexed within the surface boundaries of a mining claim owned by that company.

The application was made to a District Court of the State of Montana under the provisions of a statute of that State. The above map discloses the relative position of all of these claims and the apex of the Drum Lummon lode or vein.

This inspection was sought for the purpose of procuring evidence upon which to base a suit against the Montana Company, Limited, to recover the value of the ore extracted by that company beneath the surface of its locations, and from a vein on its dip, which apexed within the location owned by the St. Louis Company. This inspection was granted by the State District Court. The Montana Company, Limited, claiming that the statute was unconstitutional, appealed to the Supreme Court of the State, where the statute was held constitutional and the order affirmed." The Montana Company, Limited, then removed the case to the Supreme Court of the United States, claiming that the statute violated the Constitution of the United States, in that it permitted one to be deprived of his property without due process of law. This court, however, held that the statute was not in violation of any of the provisions of the Constitution of the United States and affirmed the order of the State Court. ${ }^{\circ}$ While the power of ordering an inspection and survey under similar circunstances, had been held to be inherently vested in courts of equity, this decision is a leading case upon the constitutionality and validity of such a statute.

\section{C.}

The next important litigation was a suit brought by the Montana Company, Limited, to obtain a decree for the specific performance of a certain bond given by Charles Mayger, the locator of the St. Louis claim, in settlement of an adverse claim and suit filed by the owners of the Nine-Hour claim, against the applica-

5 This case was reported in 9 Mont., p. 288.

152 U. S., 160. 
tion for a patent for the St. Louis claim. This adverse and suit were based upon allegations that the surface of the Nine-Hour location conflicted with or overlapped a portion of the surface of the St. Louis location, and that claim being the older location in point of time, the area covered by such conflict belonged to the Nine-Hour claim. The owners of the two claims met and agreed that the adverse claim should be withdrawn, the suit dismissed, and Mayger be allowed to proceed to patent, and after receiving such patent, to convey to the owners of the Nine-Hour claim a strip thirty feet wide along the southwestern side line of the St. Louis claim between corners numbered 2 and 3 of the patented description therebf. The owner of the St. Louis claim then gave a bond in the penal sum of $\$ 1,500$ to make this conveyance. This strip, ever since this settlement, has been known and described as the "Compromise Strip," and has caused extensive litigation. This compromise strip is shown on the map marked "Compromise Strip" for identification. This specific performance suit was defended on several grounds, but the defense pertaining to mining law was that the settlement of such adverse claim and suit was against public policy, fraudulent against the government, and absolutely void. The lower court, however, held to the contrary and granted the decree of specific performance. The case was appealed to the Supreme Court of Montana and this ruling was affirmed. The case was afterwards removed to the Supreme Court of the United States, where the decree appealed from was also affirmed. Pursuant to this decree a conveyance of the "Compromise Strip" was executed and delivered. This is a leading case upon the question whether such a settlement violates the Acts of Congress relative to mines.

D.

In 1893 , the St. Louis Mining Company, the then owner of the St. Louis claim, instituted suit against the Montana Mining Company (the successor to the Montana Company, Limited) to recover the value of ores extracted beneath the surface of the claims lying east of the St. Louis (owned by the Montana Mining Company) on the dip of the Drum Lummon lode or vein, between planes parallel with the end lines of the St. Louis claim dropped downward vertically through the points where the apex of the

\footnotetext{
20 Mont., 394.

8 I7I U. S., 650 .
} 
lode or vein entered into and departed from the St. Louis claim on its course or strike. The main questions litigated in this case were:

1. Did the St. Louis claim have any extralateral rights on the Drum Lummon vein or lode; and

2. If so, what was the extent of such rights?

It was contended by the Montana Mining Company that no such rights existed because by the conveyance given pursuant to the decree in the specific performance case, the compromise strip had been conveyed by a specific description "together with all minerals therein contained," and that, under this conveyance, the extralateral rights of the St. Louis claim on the Drum Lummon lode or vein were bounded on the dip of said vein, by the vertical plane of the western boundary line of the compromise strip; and because the Drum Lummon vein or lode entered into and departed from the St. Louis Mining claim through the same side line thereof. This company further contended that even if the St. Louis claim possessed any extralateral rights, they only existed between planes parallel to the end lines of the claim drawn through points where the hanging wall of the lode entered into and departed from the St. Louis claim; or, in other words, extralateral rights only existed in a case of this kind, if at all, when the entire apex of the lode was within the St. Louis surface boundaries.

The St. Louis Mining Company contended that under the statutes of the United States the St. Louis claim was entitled to extralateral rights on this incidental vein, because it was entitled to extralateral rights on is original or discovery vein; that the St. Louis claim, being the older location was entitled to extralateral rights on this vein so long as any portion of its apex was within its surface boundaries; or, in other words, between planes parallel to its end lines drawn through the points where the foot wall of the Drum Lummon lode or vein entered into and departed from the St. Louis claim. As to the language in the deed -above referred to, the St. Louis Company contended that the deed must be construed as a mining deed and not as a common law deed, and that the words above quoted added nothing to the conveyance; that such conveyance simply transferred the minerals belonging to the compromise strip as a mining location, and that no part of any lode or vein therein contained, the apex of which was not within the boundaries of the compromise strip, was con- 
veyed. The question as to the point of entrance of the lode into the St. Louis claim was not considered, as it was agreed that no ore had been extracted by the Montana Mining Company except at or near the point where the apex of the vein or lode departed from the St. Louis claim.

It was conceded that the apex of this lode on its course or strike departed from the St. Louis claim at the point where it entered the compromise strip, which belonged to the Montana Mining Company. In the first trial of this case before Judge Knowles, United States District Judge for Montana, it was conceded that the hanging wall of the lode passed out of the St. Louis ground and into the compromise strip at a point indicated upon the map as the 108 foot plane, and that the foot wall of the vein passed from the St. Louis ground and into the compromise strip at a point indicated on the map as the 133 -foot plane.

Judge Knowles ruled on the trial, contrary to the Montana Company's contention, except as to the extent of the extralateral rights as claimed by that company, and limited the St. Louis Mining Company's recovery to ore extracted on the dip of the vein, beneath the surface boundaries of the "Compromise Strip," and the Montana Company's other locations lying to the east, north of the 108-foot plane. The St. Louis company recovered a judgment for the ore thus extracted and the Montana Company removed the case to the Appellate Court of the Ninth Circuit. That Court sustained Judge Knowles in all the rulings complained of, and its opinion is reported in I02 Fed., 430. The St. Louis Company also sued out a writ of error to review the ruling of Judge Knowles as to limiting the St. Louis Company's extralateral rights to the point where the hanging wall departed from the St. Louis ground or to the 108-foot plane. The Appellate Court reversed the ruling of Judge Knowles on the extent of extralateral rights, and held that the St. Louis, being the older location in point of time, had extralateral rights on the Drum Lummon lode or vein so long as any portion of the apex was within the surface boundaries of that claim or that the extralateral rights extended to the 133 -foot plane. ${ }^{\circ}$ Both of these cases having been decided by the Appellate Court adversely to the contentions of the Montana Mining Company, that company removed the case to the Supreme Court of the United States, but that court dismissed the proceedings on the ground that there was but one

This case is reported in 104 Fed., 664 
judgment, and such judgment having been reversed by the Appellate Court under its opinion in the roth Federal, and a new trial having been ordered, no judgment existed which could be considered by the Supreme Court. ${ }^{10}$ The new trial was had in 1905, under the law as established by the Appellate Court in the roand and 104th Federal. This trial resulted in a judgment for the St. Louis Mining Company for $\$ 195,000.00$. The Montana Company again sued out a writ of error to the Appellate Court for the Ninth Circuit, where the judgment was affirmed. ${ }^{11}$ It then remoyed the case to the United States Supreme Court by certiorari, where the judgment was reversed and a new trial ordered. The reversal, however, was only upon the point that, by the language of the deed executed pursuant to the decree of. specific performance, namely, "together with all minerals therein contained," there was included all minerals contained in the Drum Lummon lode or vein which existed within the vertical boundaries of the compromise strip, even though the apex of such vein was within the surface boundaries of the St. Louis claim, and that the extralateral rights of the St. Louis clain continued to the lode on its dip after it had crossed the eastern vertical boundaries of the compromise strip. ${ }^{12}$

The case coming back for the third trial, the St. Louis Company again recovered judgment for the sum of over $\$ 203,000.00$. In the decision of the Supreme Court of the United States there was excluded from the St. Louis Company's recovery, all ore extracted by the Montana Mining Company beneath the surface of the "Compromise Strip." The Montana Mining Company again removed the case to the Appellate Court and it was set for hearing and argued on the 12th day of March of this year, but no decision as yet has been reached by that court.

E.

During the progress of the last above mentioned litigation, the St. Louis Company commenced the excavation of a tunnel, starting within the surface boundaries of the St. Louis claim and extending eastward until it crossed the west vertical boundary of the compromise strip. The intention of the St. Louis Company was to continue this tunnel across the compromise strip and

10 This case is reported in I86 U. S., 24.

12 I47 Fed., 897.

12 This opinion is found in 204 U. S., 204. 
until it encountered the Drum Lummon vein on its dip, beneath the surface of the Marble Heart claim, so that it might be able to work that part of the vein, having its apex within the St. Louis claim, after such vein had so far departed on its dip as to be underneath the surface of the Nine-Hour claim and beyond the vertical boundaries of the "Compromise Strip." The Montana Mining Company filed a bill in the United States Court for the District of Montana, to enjoin the prosecution of this tunnel through the compromise strip or into the Nine-Hour claim. This injunction was granted by Judge Knowles, affirmed by the Appellate Court in the case of St. Louis Mining Company against Montana Mining Company, ${ }^{13}$ which was afterwards removed to the Supreme Court of the United States and affirmed by that court. ${ }^{14}$

The theory of the decision was, that the statute giving extralateral rights to a vein gave the owners no right to enter upon or into a claim into which the vein dipped, in any manner or in any way save or except by following the vein from their own land, down on its dip; that no right-of-way was given for a tunnel or cross-cut through another's location. This is also a leading case upon the points decided.

The decision of Judge Knowles in the 4and Federal supra seems never to have been followed, and it is not at present considered as authority upon the questions involved.

By the decision of the Supreme Court of the United States and the Federal Court of Appeals the following important questions in mining law have been settled, namely:

I. That state statutes allowing an inspection and survey of the workings of mining claims, in order to ascertain whether a trespass has been comnitted, and if so, to determine the extent thereof, and the value of the ore extracted, for the purpose of ascertaining the necessary facts for the commencement of a suit, do not contravene the Constitution of the United States and are valid.

2. That an adverse claim and suit against the application for a patent of a mining claim may be settled by the parties, and that a bond to convey a portion of one claim after patent, given in consideration of the withdrawal of such adverse and the dismissal

18 I13 Fed., 900.

14194 U. S., 235. 
of such suit, does not contravene the mineral statutes of the United States.

3. That a mining deed which contains the language "together with all mineral therein contained" conveys that section of a vein within the vertical boundaries of the surface described in the deed, even though the apex of such vein lies outside of such boundaries. LAW-Galley $14 \ldots \ldots \ldots \ldots$..... SHRDLU VBGKJ WYP

4. That one owning extralateral rights on a vein may convey a section of such vein on its dip without disturbing his extralateral rights beyond the section conveyed.

5. That extralateral rights exist upon a vein which enters and departs from the same boundary of a location, but only between vertical planes parallel with the end lines of the claim, dropped through the point of entrance and departure of the vein on its course.

6. That in such case the prior location is entitled to the full extralateral rights on the vein so long as any portion of the apex thereof is found within its surface boundaries.

7. That the Act of Congress granting extralateral rights to a vein gives no right of entry upon, across or into another location, but only the right to follow the vein on its dip beyond the vertical boundaries of the claim owning the extralateral rights.

None of these questions had ever before been decided by any Federal Court of last resort, and consequently each and all the cases above considered were leading cases upon the points involved.

John B. Clayberg. 